\title{
IMPLEMENTASI KEBIJAKAN PENATAAN PEDAGANG KAKI LIMA
}

\author{
Abang Zainudin, Sugianto \\ Fakultas Ilmu Sosial dan Ilmu Politik Universitas Kapuas \\ Email : ab jay57@yahoo.co.id
}

\begin{abstract}
Abstrak : Salah satu tujuan dari penyusunan Tata Ruang Wilayah (RTRW) Kabupaten Sintang 2006 2016 adalah dalam rangka memberikan pedoman teknis pemanfaatan ruang bagi kegiatan sosial ekonomi masyarakat, pendanaan, aspek hukum dan peraturan. Guna mewujudkan tujuan pengembangan wilayah tersebut, maka Pemerintah Daerah Kabupaten Sintang mengeluarkan Pemerintah Daerah Kabupaten Sintang Nomor 9 Tahun 2011 Tentang Penataaan Pedagang Kaki Lima di Kabupaten Sintang.Dalam implementasi kebijakan penataan Pedagang Kaki Lima di Kecamatan Sintang, di pengaruhi oleh empat faktor yaitu faktor komunikasi, sumber daya, disposisi atau sikap Aparatur dan struktur birokrasi. Faktor komunikasi, disposisi, struktur birokrasi dan Sumber daya manusia merupakan faktor pendukung dalam implementasi kebijakan penataan Pedagang Kaki Lima di Kecamatan Sintang, sedangkan faktor sumber daya peralatan dan anggaran merupakan faktor penghambat dalam dalam implementasi kebijakan penataan Pedagang Kaki Lima di Kecamatan Sintang. Sehingga dapat dikatakan bahwa implemntasi kebijakan penataan Pedagang Kaki Lima di Kecamatan Sintang belum dapat dilaksanakan sebagaimana mestinya sesuai dengan Peraturan Daerah Nomor 9 Tahun 2011.
\end{abstract}

Kata Kunci : Implementasi, Penataan, PKL

Dalam rangka memberikan pedoman teknis pemanfaatan ruang bagi kegiatan sosial ekonomi masyarakat, pendanaan, aspek hukum dan peraturan. Wilayah perencanaan dalam penyusunan Tata Ruang Wilayah (RTRW) Kabupaten Sintang 2006 - 2016 meliputi seluruh wilayah administrasi Kabupaten yang terdiri dari 14 kecamatan yaitu : kecamatan Ambalau, Serawai, Dedai, Kayan Hilir, Kayan Hulu, Kelam Permai, Sintang, Binjai, Ketungau Hulu, Ketengah Tengah, Ketungau Hilir, Sepauk, Sungai Tebelian dan Tempunak. Sesuai dengan Rencana Tata Ruang Wilayah (RTRW) Kabupaten Sintang 2006 - 2016, pemanfaatan potensi ruang di wilayah dilakukan dengan mengoptimalkan ruang, terutama dalam rangka mengembangkan kegiatan ekonomi, pemanfaatan ruang dilakukan dan diarahkan untuk memberikan nilai tambah untuk peningkatan pendataan masyarakat, pengembangan wilayah ditunjukan untuk memberikan hasil yang sebesar- besarnya dan manfaat bagi kesejahteraan masyarakat. Pendekatan yang dilakukan melalui peraturan ruang yang adil dan mengembangkan kemitraan kerja yang saling mendukung.

Penataan ruang diarahkan untuk menumbuh kembangkan kesadaran atas hak dan kewajiban masyarakat dan stakeholdrs lainya dalam manfaatan ruang sesuai dengan rencana tata ruang yang telah ditetapkan. Meningkatkan kesadaran kepada pelaku pembanguanan disini maksudnya bahwa masyarakat bukanlah sebagai obyek pemanfatan ruang, tetapi justru mereka lah pelaku dan pemanfaat utama yang seharusnya terlibat dari proses awal hingga akhir dalam manfaatan ruang.

Guna mewujudkan tujuan pengembangan wilayah tersebut, maka Pemerintah Daerah Kabupaten Sintang telah menyusun Satuan Wilayah Pengembangan (SWP) kedalam beberapa sub wilayah pembangunan yang meliputi bagian 
Utara, bagian Tengah, bagian Selatan dan bagian Barat. Penetapan SWP diarahkan untuk melaraskan rencana pembangunan dan potensi wilayah serta meningkatkan aksirelaksi proses perkembangan termasuk pemerataan hasil-hasil pembangunan. Secara keseluruhan di Kabupaten Sintang telah dikelompokan menjadi 5 (lima) SWP, salah satunya adalah satuan wilayah pembangunan wilayah 1 (Sintang Raya) yang meliputi Kecamatan Sintang, Binjai Hulu, Kelam Prmai dan Sungai Tebelian. SWP 1 ini ditetapkan sebagai pusat pelayanan sosial, ekonomi dan jasa tingkat Kabupaten, pusat wilayah pengembangan pasar, pusat pengembangan obyak wisata, dan pusat pemukiman.

Jika melihat dari SWP Kabupaten Sintang tersebut seyogyanya Kecamatan Sintang sebagai pusat ibukota Kabupaten Sintang merupakan wilayah yang bersih, indah, tetapi rapi dan menjadi barometer bagi kota-kota lainnya di Kabupaten Sintang. Hal ini menjadi suatu kewajaran mengingat Kecamatan Sintang bukan hanya sebagai pusat pengembangan wilayah 1 di Kabupaten Sintang, melainkan juga merupakan sebagai pusat ibukota Kabupaten Sintang.Dalam kenyataannya di Kecamatan Sintang suasana yang nyaman sebagaimana yang diharapan tersebut diatas masih belum terlaksana sebagaimana yang diagendakan pada Renacana Tata Ruang Wilayah (RTRW) Kabupaten Sintang 2006 - 2016, dimana berdasarkan pengamatan penulis disetiap tempat perbelanjaan (pasar/toko) yang terdapat di Kecamatan Sintang seperti masih ditemukan pedagang kaki lima yang melakukan usahanya terkesan liar atau tidak dilengkapi dengan Surat Izin Usaha Perdagangan (SIUP).

Keberadaan pedagang kaki lima di Kecamatan Sintang bukan hanya tidak sesuai konsep Tata Ruang Wilayah Kabupaten Sintang semata, melainkan keberadaan pedagang kaki lima ini terkadang menganggu arus lalu lintas (tranportasi) dalam kota, sebagai contoh setiap hari yang terjadi di kawasan pasar Sungai Durian Kelurahan Kapuas Hulu dan Pasar Inpres Kelurahan Tanjung Puri, dimana akibat aktivitas pedagang kaki lima yang sudah memanfaat ruang jalan berdampak pada kemacetan lalu lintas. Pemerintah Daerah Kabupaten Sintang telah membuat Peraturan Daerah Kabupaten Sintang Nomor 5 Tahun 1999 tentang Retrubusi Mendirikan Bangunan yang ditindaklanjuti dengan Surat Pengumuman Bupati Sintang Nomor 510/2821/perindak/2007 Perihal Larangan Berjualan Bukan Pada Tempatnya seperti di trotoar dan pinggir jalan utama di wilayah Kabupaten Sintang. Selanjutnya pada Tahun 2011 telah dikeluarkan Pemerintah Daerah Kabupaten Sintang Nomor 9 Tahun 2011 Tentang Penataaan Pedagang Kaki Lima di Kabupaten Sintang. Dalam Perda Nomor 9 Tahun 2011 pasal 2 ayat 2 berbunyi:"'lokasi PKL ditetapkan oleh Bupati", dan pasal 3 ayat 1 berbunyi: setiap PKL wajib memiliki izin penggunaan lokasi dan kartu identitas dari Bupati atau Pejabat yang ditujuk", serta pasal 9 ayat 1 huru $\mathrm{b}$ ditegaskan bahwa :"setiap PKL dilarang melakukan kegiatan usaha pada tempat diluar lokasi yang telah ditetapkan".

Bedasarkan data yang dikeluarkan oleh Dinas Perindustrian Perdagangan Koperasi dan UKM tahun 2014 diketahui jumlah PKL terdata yang terdapat di Kecamatan Sintang adalah 390 orang yang terdiri dari 290 orang berada pada tempat yang bukan lokasi yang telah ditetapkan oleh Pemerintah Daerah Kabupaten Sintang, dan 100 orang menempati lokasi yang disedikan oleh Pemerintah Daerah Kabupaten Sintang. Untuk lebih mengetahui secara lebih jelas mengenai 
keberadaan PKL di Kecamatan Sintang Perindustrian Perdagangan Koperasi dan UKM sebagaimana data yang diperoleh dari Dinas tahun 2014 dapat dilihat pada tabel berikut ini :

Tabel 1. Data Pedagang Kaki Lima (PKL) di Kecamatan Sintang

\begin{tabular}{|l|l|l|l|l|l|}
\hline \multirow{2}{*}{ No } & \multicolumn{1}{|c|}{ Lokasi PKL } & \multicolumn{3}{c}{ Jumlah PKL (orang) } & \multirow{2}{*}{ Keterangan } \\
\cline { 3 - 6 } & & 2012 & 2013 & 2014 & \\
\hline 1 & Jl. Kol. Sugiono (Depan MM Intan Market) & 50 & 26 & 50 & Lokasi yang dilarang \\
\hline 2 & Jl. WR. Supratman (Sekitar BRI Unit) & 31 & 81 & 31 & Lokasi yang dilarang \\
\hline 3 & Jl. MT. Haryono (Depan SMAN 2 Sintang) & 3 & 6 & 10 & Lokasi yang dilarang \\
\hline 4 & Jl. Brigjen Katamso (Lorong / Gang) & 17 & 16 & 16 & Lokasi yang dilarang \\
\hline 5 & Jl. Majapahit & 10 & 10 & 10 & Lokasi yang dilarang \\
\hline 6 & Jl. DI Panjaitan & 4 & 17 & 4 & Lokasi yang dilarang \\
\hline 7 & Jl. Jend. Sudirman - Tugu Jl. Wirapati & 15 & 15 & 15 & Lokasi yang dilarang \\
\hline 8 & Komplek Terminal Sungai Durian & 30 & 15 & 35 & Lokasi yang dilarang \\
\hline 9 & Jl. Patimura (Sekitar Ruko H.Ibrahim) & 20 & 12 & 7 & Lokasi yang dilarang \\
\hline 10 & Jl. PKP. Mujahidin (Sekitar Tugu BI) & 34 & 35 & 60 & Lokasi yang dilarang \\
\hline 11 & Jl. Alambhana Wanawai & 5 & 8 & 17 & Lokasi yang dilarang \\
\hline 12 & Jl. MT. Haryono (Komp.BTN Cipta Mandiri) & 18 & 20 & 20 & Lokasi yang dilarang \\
\hline 13 & Jl. YC. Oevang Oerai (Kawasan Simpang Lima) & 5 & 9 & 15 & Lokasi yang dilarang \\
\hline 14 & Jl. Brigjen Katamso & 80 & 80 & 80 & Lokasi yang ditetapkan \\
\hline 15 & Jl. PKP. Mujahidin (Pasar Seni dan Galeri) & 20 & 20 & 20 & Lokasi yang ditetapkan \\
\hline & & 342 & 370 & 390 &
\end{tabular}

Sumber : Data diolah dari Dinas Perindustrian Perdagangan Koperasi dan UKM, tahun 2016

Data tabel 1 dapat dikatakan bahwa implementasi peraturan mengenai penataan Pedagang Kaki Lima belum dapat dilaksanakan sebagaimana mestinya. Ini terlihat dengan jelas bahwa pada tahun 2012 ada 242 PKL yang menempati lokasi yang dilarang Pemerintah Daerah Kabupaten Sintang, pada tahun 2013 bertambah menjadi 270 orang dan selanjutnya pada tahun 2014 bertambah menjadi 290 PKL yang menempati lokasi yang dilarang Pemerintah Daerah Kabupaten Sintang. Faktor lainnya yang menyebabkan terjadikan Pedagang
Kaki Lima berjualan pada tempat-tempat yang dilarang oleh Pemerintah Daerah Kabupaten Sintang tidak terlepas dari faktor yang berhubungan dengan peluang kerja dan kesempatan kerja serta terbatasnya lowongan kerja sehingga banyak menibulakan pengangguran. Besadarkan data dari Dinas Perindustrian Perdagangan Koperasi dan UKM Kabupaten Sintang tahun 2015, pendaftaran dan lapangan kerja, penempatan kerja dan penghapusan kerja penduduk Kecamatan Sintang tahun 2015 dapat dilihap pada tabel berikut ini :

Tabel 2. Pendaftaran Dan Lapangan Kerja, Penempatan Kerja Dan Penghapusan Kerja Penduduk Kecamatan Sintang Tahun 2014 s/d 2015

\begin{tabular}{|c|c|c|c|c|c|c|c|c|c|c|c|c|c|}
\hline \multirow{2}{*}{ No } & \multirow{2}{*}{ Kegiatan } & \multicolumn{12}{|c|}{ Bulan } \\
\hline & & 1 & 2 & 3 & 4 & 5 & 6 & 7 & 8 & 9 & 10 & 11 & 12 \\
\hline 1 & $\begin{array}{l}\text { Pendaftaran dan } \\
\text { lapangan kerja }\end{array}$ & 577 & 600 & 581 & 600 & 610 & 682 & 722 & 786 & 0 & 0 & 0 & 0 \\
\hline 2 & Penempatan kerja & 544 & 542 & 336 & 542 & 577 & 624 & 668 & 744 & 0 & 0 & 0 & 0 \\
\hline 3 & Pengahapusan & 33 & 58 & 245 & 58 & 33 & 58 & 54 & 0 & 0 & 0 & 0 & 0 \\
\hline 4 & Sisa Akhir & 0 & 0 & 0 & 0 & 0 & 0 & 0 & 42 & 0 & 0 & 0 & 0 \\
\hline 5 & Terdaftar & 10 & 19 & 31 & 19 & 10 & 72 & 35 & 64 & 0 & 0 & 0 & 0 \\
\hline
\end{tabular}

Sumber : Data diolah dari Dinas Perindustrian Perdagangan Koperasi dan UKM, Pebruari tahun 2016

Apabila aktivitas pedagang kaki lima ini tidak diatur atau ditata dengan baik dan benar oleh Pemerintah Kabupaten Sintang, diyakini akan menimbulkan masalah pembangunan daerah ini dikemudian hari.Hal ini mengingat dibeberapa kota di Indonesia sering dihadapi dengan permasalahan yang berkaitan dengan penataan Pedagang Kaki Lima. Kondisi ini akan tambah parah lagi seiringan dengan gerak laju pertumbuhan penduduk di Kabupaten Sintang yang semakin pesat. Dalam 
pencapaian tujuan sebuah organisasi atau lembaga tentu saja tidak terlepas dari pemasalahan yang dihadapi. Oleh karena itu dalam pencapaian tujuan suatu organisasi diperlukan kebijakan untuk mengatasi segala macam bentuk masalah yang menjadi kendala dalam pencapaian tujuan yang telah ditetapkan sebelumnya.Widodo (2007:9-10) menegaskan bahwa" kebijakan memiliki kesamaan posisi dan sudut pandang pada satu sisi dan pada sisi lain menunjukan pada suatu rangkaian tindakan tertentu.Semantara itu, posisi kebijakan hanya sebagai sebuah peraturan semata". Selanjutnya Friedrich (dalam Wahab, 2001:3) memberikan pengertian kebijakan sebagai berikut : "kebijakan adalah suatu tindakan yang mengarah pada suatu tujuan yang diusulkan oleh seseorang, kelompok atau pemerintah dalam lingkungan tertentu sehubungan dengan adanya hambatan-hambatan tertentu supaya mencari peluang untuk mencapai tujuan yang mewujudkan sasaran yang inginkan". Definisi kebijakan di atas, pada dasarnya selalu berorientasi pada tujuan atau sasaran yang ingin dicapai. Dengan demikian dapat ditegaskan bahwa kebijakan adalah suatu tindakan program yang mengarah pada pencapaian tujuan yang diusulkan oleh seseorang, kelompok atau pemerintah dalam lingkungan tertentu, sehubungan dengan adanya hambatan-hambatan tertentu dalam menwujudkan sasaran yang diinginkan.

Pada hakekatnya untuk mencapai suatu tujuan tersebut diatas diperlukan sebuah kebijakan publik. Kebijakan publik dibuat untuk menyelesaikan masalah-masalah publik yang mendesak untuk segara ditangani dan terdapat alternatif-alternatif untuk digunakan dalam pemecahan masalah publik tersebut. Kemudian kebijakan publik (public policy) merupakan serangkaian pilihan yang kurang lebih saling berhubungan (termasuk keputusan-keputusan untuk bertindak) yang dibuat oleh badan atau pejabat pemerintah, diformulasikan dalam bidangbidang isu dari pertahanan, energi, dan kesehatan sampai kependidikan, kesejahteraan dan sampai kejahatan. Selanjutnya pengertian kebijakan publik Menurut Dunn (dalam Islamy, 2000:31) sebagai suatu tindakan atau sikap yang dipilih oleh pemerintah untuk dilakukan atau tidak dilakukan. Berangkat dari pengertian tersebut, bahwa kebijakan publik sangat luas bidang yang menjadi fokus perhatiannya dan bertujuan untuk dapat menyelesaikan permasalahan publik disegala bidang kehidupan dan memerlukan kajian dari interdisiplin keilmuan. Thoha (2003:68) mengatakan bahwa :"proses kebijakan publik yang secara pokok menetapkan garis-garis umum dalam rangka memecahkan persoalan-persoalan masyarakat, tidak lepas dari peranan lembaga-lembaga pemerintah". Untuk melaksanakan kebijakan tersebut dibutuhkan sistem dinamika birokrasi (Thomson dalam Thoha, 2003:68). Hal ini berarti setelah kebijakan tersebut dibuat, maka untuk memecahkan masalah dan memberikan maafaat kepada masyarakat, kebijakan tersebut harus diimplementasikan. Selanjutnya suatu kebijakan yang baik, tanpa diimbangi dengan pelaksanaan yang baik tidak akan pernah mencapai tujuan sebagaimana yang diharapkan, hal tersebut diungkapkan oleh Daniel (dalam Wahab, 2001:65).

Kemudian sebelum sebuah kebijakan diimplementasikan terlebih dahulu kebijakan tersebut harus diukur, supaya dapat dilaksanakan secara baik. Menurut Bridgman dan Davis (dalam Setiyono :2004;64) kebijakan publik sebagai produk birokrasi yang baik harus memenuhi kriteria seperti tepat (appropriate), efisien (efficient), efektif (effective), terbuka (transparant), adil (equitable), didukung oleh stakeholders (supported by stakeholders), konsisten (consistent), fleksibel (flexible), memiliki target (targeted), menyeluruh (comprehensive), merupakan program berkelanjutan (sustanable), memiliki tolak ukur yang jelas (clear meassurement), dan mudah dipahami (comprehensible). Dengan ukuran-ukuran tersebut tentu akan membantu keberhasilan pelaksanaan dari suatu kebijakan. Dimensi implementasi yang menjadi konsep penting dalam prosedur implementasi menurut terdiri dari perubahan, kontrol dan kepatuhan bertindak. Dapat disimpulkan bahwa ketiga dimensi terrsebut saling 
terkait. Selain itu dalam implementasi kebijakan harus diperhatikan hambatan secara internal dan eksternak organisasi, pelaksana kontrol, dan tingkat kepatuhan dari pada pelaksana kebijakan.

Menurut Webster (dalam Wahab, 2000:64) merumuskan tentang implementasi adalah sebagai berikut : "to implementation (mengimplementasikan) berarti to provide that means for carring aut; (menyediakan sarana untuk menyediakan sesuatu); to give practical effect to (menimbulkan dampak/akibat terhadap sesuatu)". Sejalan dengan pendapat di atas dapat dikatakan bahwan implementasi merupakan sebuah proses untuk menjalankan suatu kebijakan yang telah disusun.Van Meter dan Van Horn (sebagaimana dikutip dalam wahab 2000:6) merumuskan implementasi :" those actions by public or private individual (or group) there are dirrect at the achievements of objectives for in prior policy decisions; (tindakan-tindakan yang dilakukan, baik yang dilakukan oleh individuindividu/pejabat-pejabat atau kelompok pemerintah atau swasta yang diarahkan pada tercapainya tujuan-tujuan yang telah ditetapkan dalam keputusan kebijakan". Nugroho (2011: 618) mengatakan : Implementasi kebijakan pada prinsipnya adalah cara agar sebuah kebijakan dapat mencapai tujuannya".

Dilihat dari definisi di atas, bahwa implementasi kebijakan merupakan suatu tindak lanjut dari pembuatan kebijakan yang dilakukan baik oleh orang perorangan atau kelompok. Selanjutnya implementasi suatu kebijakan dapat saja dilakukan oleh pihak swasta atau pun pemerintah. Disamping itu juga bahwa implemetasi kebijakan diarahkan untuk mencapai suatu sasaran. Dalam arti kata bahwa dengan terimplementasinya suatu kondisi dari masa sebelumnya. Widodo (2007:59) menjelaskan : "implementasi kebijakan publik merupakan salah satu tahapan dari proses kebijakan publik (public policy process) sekaligus studi yang sangat crucial.Di katakana crucial karena bagaimanapun baiknya suatu kebijakan, kalau tidak dipersiapakan dan direncanakan...,maka tujuan kebijakan tidaka akan bias diwujudkan". Di sisi lain,
Nugroho (2004:158), juga mengemukakan bahwa :" implementasi kebijakan pada prinsipnya adalah cara agar sebuah kebijakan dapat mencapai tujuannya, tidak lebih dan tidak kurang".

Nugroho (2004:165), mengatakan:"pada prinsipnya terdapat dua pemilihan jenis teknik atau model implementasi kebijakan. Pemilihan pertama adalah implementasi kebijakan yang berpola dari atas ke bawah (top bottomer) versus dari bawah ke atas (bottom-topper), dan pemilihan implementasi yang berpola paksa (command-andcontrol) dan mekanisme pasar (economic incentive)". Pendekatan top bottomer bertolak dari perspektif keputusan kebijakan yang tetap oleh para pembuat kebijakan. Focus analisisnya berkisar pada masalah pencapaian tujuan yang secara formal telah diterapkan oleh pembuat kebijakan. Pendekatan bottom-topper adalah antitesis dari pendekatan top bottomer. Pendekatan bottomtopper memulai analisisnya dengan mengimplementasikan jaringan mengenai aktoraktor yang terlibat dalam implementasi kebijakan pada satu atau lebih wilayah lokal baik dalam perencanaan, pembiayaan, maupun pelaksanaan program pemerintah dan non pemerintah. Jadi metode analisisnya bergerak dari perspektif birokrasi tingkat bawah ke perspektif birokrasi pada tingkat atas. Pendekatan ini tidak secara tegas menganalisis pencapaian tujuan yang secara formal ditetapkan oleh pembuat kebijakan. Di samping itu pula pendengkatan ini cenderung lebih memfokuskan perhatianya pada pemahaman tentang interaksi yang terjadi antara faktor di dalam jaringan kebijakan.

Pemerintah Daerah Kabupaten Sintang telah mengeluarkan Peraturan Daerah Nomor 9 Tahun 2011 Tentang Penataaan Pedagang Kaki Lima di Kabupaten Sintang. Perda tersebut merupakan suatu kebijakan publik yang keluarkan oleh Pemerintah Daerah Kabupaten Sintang untuk pengelolaan atau penataan Pedagang Kaki Lima yang terdapat di Wilayah Kabupaten Sintang. Dalam implementasi Pemerintah Daerah Kabupaten Sintang Nomor 9 Tahun 2011 memerlukan keterlibatan semua pihak terkait atau 
terdapat banyak faktor yang menentukan berhasil tidaknya implementasi kebijakan tersebut. Peraturan Daerah Nomor 9 Tahun 2011 Tentang Penataaan Pedagang Kaki Lima di Kabupaten Sintang, dikatakan sebagai suatu kebijakan publik sesuai dengan pendapat Dwijowijoto (2004: 7) yang mengatakan " kebijakan publik adalah kebijakan yang dibuat oleh organisasi publik. Jadi organisasi publik identik dengan pemerintah". Selanjutnya dalam buku yang sama Dwijowijoto (2004 : 51-52) mengatakan :Kebijakan publik adalah jalan mencapai tujuan bersama yang dicita-citakan. Jika cita-cita bangsa Indonesia adalah mencapai masyarakat yang adil dan makmur berdasarkan Pancasila (Ketuhanan, Kemanusiaan, Persatuan, Demokrasi, dan Keadilan) dan UUD 1945 ( Negara Republik Indonesia yang berdasarkan hukum dan tidak semata-mata kekuasaan), maka kebijakan publik adalah seluruh prasarana dan sarana untuk mencapai 'tempat tujuan' tersebut. Dari sini kita bisa meletakan "kebijakan publik" sebagai manajemen pencapaian tujuan nasional". Jadi, untuk sementara dapat kita simpulkan bahwa : (1) kebijakan publik mudah untuk dipahami, karena maknanya adalah "hal-hal yang dikerjakan untuk mencapai tujuan nasional”, (2) kebijakan publik mudah diukur, karena ukurannya jelas yakni sejauh mana kemajuan pencapaian cita-cita sudah ditempuh.

Hogwod dan Gunn (dalam Wahab, 2001:61) telah membagi pengertian kegagalan kebijaksanaan (policy failure) dalam dua katagori, yaitu : Non implementation (tidak terimplementasikan) dan Unsuccessful implementation (implementasi yang tidak berhasil). Menurut Wahab (2001:62) yang dimaksud dengan tidak terimplementasikan mengandung arti bahwa suatu kebijaksanaan tidak dilaksanakan sesuai dengan rencana, mungkin karena pihakpihak yang terlibat dalam pelaksanaannya tidak mau bekerjasama atau mereka telah bekerja tidak efisien atau tidak sepenuhnya menguasai permasalahan. Sedangkan implementasi yang tidak berhasil biasanya terjadi manakala suatu kebijakasanaan telah dilaksanaan sesuai dengan rencana, namun mengingat kondisi eksternal ternyata tidak menguntungkan (misalnya pergantian kekuasaan, bencana alam).

Oleh karena itu dalam proses implementasi kebijaksanaan perlu mendapat perhatian yang seksama. Mazmanian dan Sabatier (dalam Subarsono, 2005:94) merumuskan :" ada tiga kelompok variable yang mempengaruhi keberhasilan implementasi, yakni 1). Karakteristik dari masalah (tractability of the problem); 2).Karakteristik kebijakan/undang-undang (ability ot statute to structure implementation); 3). Variabel lingkungan (nonstaturory variables affecting implementation). Memperhatikan pandangan tersebut, proses implementasi kebijakan mengandung unsur, yaitu (a) masalah yang ingin dipecahkan; (b) mempertegas tujuan yang ingin dicapai; (c) cara menstruktur dan mengatur; (d) mengesahkan Undang-undang dengan disertai output dalam bentuk pelaksanaan kebijakan oleh badan (instansi) yang melaksanakannya; (e) kesedian kelompok sasaran untuk melaksanakan tujuan itu; (f) dampak nyata baik yang dikehendaki atau yang tidak dikehendaki dari output kebijakan; (g) upaya untuk melakukan perbaikan-perbaikan.

Berkenaan dengan itu, Weimer dan Vining (dalam Subarsono, 2005:103) mengungkapkan : “ ada tiga kelompok variabel besar yang dapat mempengaruhi keberhasilan implementasi suatu program, yakni : 1). Logika kebijakan; 2). Lingkungan tempat kebijakan; 3). Kemampuan implementor kebijakan". Untuk meneliti mengenai implementasi kebijakan penatan Pedangan Kaki lima di Kecamatan Sintang, Peneliti akan menggunakan pendapat Edward III yang mengatakan bahwa implementasi kebijakan dipengaruhi variabel komunikasi,sumber daya, disposisi/ sikap birokrasi dan struktur birokrasi. Edward III (sebagai mana dikutip dalam Widodo, 2007:96) yang mengatakan bahwa :" empat faktor atau variabel yang berpengaruh terhadap keberhasilan atau kegagalan implementasi kebijakan antara lain meliputi faktor Communication (komunikasi), resources (sumber daya), dispositions (disposisi) dan bureaucratic 
structure (struktur birokrasi)". Alasan peneliti mengunakan teori Edward III adalah dikarenakan menurut peneliti, teori Edward III sangat relevan dan tepat digunakan untuk mengkaji dan menganalisis implementasi kebijakan di Negara sedang berkembang khususnya pada tataran local atau daerah yang terdapat di Negara Indonesia seperti di Kabupaten Sintang.

Birokrasi merupakan salah-satu institusi yang paling sering bahkan secara keseluruhan menjadi pelaksana kegiatan. Keberadaan birokrasi tidak hanya dalam struktur pemerintah, tetapi juga ada dalam organisasi-organisasi swasta, institusi pendidikan dan sebagainya. Bahkan dalam kasuskasus tertentu birokrasi diciptakan hanya untuk menjalankan suatu kebijakan tertentu. Ripley dan Franklin dalam Winarno (2005:149-160) mengidentifikasi enam karakteristik birokrasi sebagai hasil pengamatan terhadap birokrasi di Amerika Serikat, yaitu: Birokrasi diciptakan sebagai instrumen dalam menangani keperluan-keperluan publik (public affair). Birokrasi merupakan institusi yang dominan dalam implementasi kebijakan publik yang mempunyai kepentingan yang berbeda-beda dalam setiap hierarkinya. Birokrasi mempunyai sejumlah tujuan yang berbeda. Fungsi birokrasi berada dalam lingkungan yang kompleks dan luas. Birokrasi mempunyai naluri bertahan hidup yang tinggi dengan begitu jarang ditemukan birokrasi yang mati. Birokrasi bukan kekuatan yang netral dan tidak dalam kendali penuh dari pihak luar.

Implementasi kebijakan yang bersifat kompleks menuntut adanya kerjasama banyak pihak. Ketika strukur birokrasi tidak kondusif terhadap implementasi suatu kebijakan, maka hal ini akan menyebabkan ketidakefektifan dan menghambat jalanya pelaksanaan kebijakan.Berdasakan penjelasan di atas, maka memahami struktur birokrasi merupakan faktor yang fundamental untuk mengkaji implementasi kebijakan publik. Menurut Edwards III dalam Winarno (2005:150) terdapat dua karakteristik utama dari birokrasi yakni: "Standard Operational Procedure (SOP) dan fragmentasi"." Standard operational procedure (SOP) merupakan perkembangan dari tuntutan internal akan kepastian waktu, sumber daya serta kebutuhan penyeragaman dalam organisasi kerja yang kompleks dan luas". (Winarno, 2005:150). Ukuran dasar SOP atau prosedur kerja ini biasa digunakan untuk menanggulangi keadaan-keadaan umum diberbagai sektor publik dan swasta. Dengan menggunakan SOP, para pelaksana dapat mengoptimalkan waktu yang tersedia dan dapat berfungsi untuk menyeragamkan tindakan-tindakan pejabat dalam organisasi yang kompleks dan tersebar luas, sehingga dapat menimbulkan fleksibilitas yang besar dan kesamaan yang besar dalam penerapan peraturan.

Berdasakan hasil penelitian Edward III yang dirangkum oleh Winarno $(2005: 152)$ menjelaskan bahwa: SOP sangat mungkin dapat menjadi kendala bagi implementasi kebijakan baru yang membutuhkan cara-cara kerja baru atau tipetipe personil baru untuk melaksanakan kebijakankebijakan. Dengan begitu, semakin besar kebijakan membutuhkan perubahan dalam cara-cara yang lazim dalam suatu organisasi, semakin besar pula probabilitas SOP menghambat implementasi.Namun demikian, di samping menghambat implementasi kebijakan SOP juga mempunyai manfaat. Organisasi-organisasi dengan prosedur-prosedur perencanaan yang luwes dan kontrol yang besar atas program yang bersifat fleksibel mungkin lebih dapat menyesuaikan tanggung jawab yang baru daripada birokrasibirokrasi tanpa mempunyai ciri-ciri seperti ini.

Sifat kedua dari struktur birokrasi yang berpengaruh dalam pelaksanaan kebijakan adalah fragmentasi. Edward III dalam Winarno (2005:155) menjelaskan bahwa "fragmentasi merupakan penyebaran tanggung jawab suatu kebijakan kepada beberapa badan yang berbeda sehingga memerlukan koordinasi". Pada umumnya, semakin besar koordinasi yang diperlukan untuk melaksanakan kebijakan, semakin berkurang kemungkinan keberhasilan program atau kebijakan.Fragmentasi mengakibatkan pandanganpandangan yang sempit dari banyak lembaga 
birokrasi. Hal ini akan menimbulkan konsekuensi pokok yang merugikan bagi keberhasilan implementasi kebijakan. Berikut hambatanhambatan yang terjadi dalam fregmentasi birokrasi berhubungan dengan implementasi kebijakan publik (Budi Winarno,2005:153-154): Tidak ada otoritas yang kuat dalam implementasi kebijakan karena terpecahnya fungsi-fungsi tertentu ke dalam lembaga atau badan yang berbeda-beda. Di samping itu, masing-masing badan mempunyai yurisdiksi yang terbatas atas suatu bidang, maka tugas-tugas yang penting mungkin akan terlantarkan dalam berbagai agenda birokrasi yang menumpuk". Pandangan yang sempit dari badan yang mungkin juga akan menghambat perubahan. Jika suatu badan mempunyai fleksibilitas yang rendah dalam misi-misinya, maka badan itu akan berusaha mempertahankan esensinya dan besar kemumgkinan akan menentang kebijakankebijakan baru yang membutuhkan perubahan.

Syarat berjalannya suatu organisasi adalah kepemilikan terhadap sumberdaya (resources). Edwards III (1980:11) mengkategorikan sumber daya organisasi terdiri dari : "Staff, information, authority, facilities; building, equipment, land and supplies". Edward III (1980:1) mengemukakan bahwa sumberdaya tersebut dapat diukur dari aspek kecukupannya yang di dalamnya tersirat kesesuaian dan kejelasan; "Insufficient resources will mean that laws will not be enforced, services will not be provided and reasonable regulation will not be developed ".Tachjan (2006:135) mengatakan :"sumber daya diposisikan sebagai input dalam organisasi sebagai suatu sistem yang mempunyai implikasi yang bersifat ekonomis dan teknologis. Secara ekonomis, sumber daya bertalian dengan biaya atau pengorbanan langsung yang dikeluarkan oleh organisasi yang merefleksikan nilai atau kegunaan potensial dalam transformasinya ke dalam output. Sedang secara teknologis, sumberdaya bertalian dengan kemampuan transformasi dari organisasi”.

Menurut Edward III dalam Agustino (2006:158-159), sumberdaya merupakan hal penting dalam implementasi kebijakan yang baik.
Indikator-indikator yang digunakan untuk melihat sejauhmana sumberdaya mempengaruhi implementasi kebijakan terdiri dari: Staf. Sumber daya utama dalam implementasi kebijakan adalah staf atau pegawai (street-level bureaucrats). Kegagalan yang sering terjadi dalam implementasi kebijakan, salah-satunya disebabkan oleh staf/ pegawai yang tidak cukup memadai, mencukupi, ataupun tidak kompeten dalam bidangnya. Penambahan jumlah staf dan implementor saja tidak cukup menyelesaikan persoalan implementasi kebijakan, tetapi diperlukan sebuah kecukupan staf dengan keahlian dan kemampuan yang diperlukan (kompeten dan kapabel) dalam mengimplementasikan kebijakan. Informasi. Dalam implementasi kebijakan, informasi mempunyai dua bentuk yaitu: pertama, informasi yang berhubungan dengan cara melaksanakan kebijakan. Kedua, informasi mengenai data kepatuhan dari para pelaksana terhadap peraturan dan regulasi pemerintah yang telah ditetapkan. Wewenang. Pada umumnya kewenangan harus bersifat formal agar perintah dapat dilaksanakan secara efektif. Kewenangan merupakan otoritas atau legitimasi bagi para pelaksana dalam melaksanakan kebijakan yang ditetapkan secara politik. Ketika wewenang tidak ada, maka kekuatan para implementor di mata publik tidak dilegitimasi, sehingga dapat menggagalkan implementasi kebijakan publik. Tetapi dalam konteks yang lain, ketika wewenang formal tersedia, maka sering terjadi kesalahan dalam melihat efektivitas kewenangan. Di satu pihak, efektivitas kewenangan diperlukan dalam implementasi kebijakan; tetapi di sisi lain, efektivitas akan menyurut manakala wewenang diselewengkan oleh para pelaksana demi kepentingannya sendiri atau kelompoknya. Fasilitas. Fasilitas fisik merupakan faktor penting dalam implementasi kebijakan. Implementor mungkin mempunyai staf yang mencukupi, kapabel dan kompeten, tetapi tanpa adanya fasilitas pendukung (sarana dan prasarana) maka implementasi kebijakan tersebut tidak akan berhasil.

Edward III dalam Winarno (2005:142-143) mengemukakan "kecenderungan-kecenderungan 
atau disposisi merupakan salah-satu faktor yang mempunyai konsekuensi penting bagi implementasi kebijakan yang efektif". Jika para pelaksana mempunyai kecenderungan atau sikap positif atau adanya dukungan terhadap implementasi kebijakan maka terdapat kemungkinan yang besar implementasi kebijakan akan terlaksana sesuai dengan keputusan awal. Demikian sebaliknya, jika para pelaksana bersikap negatif atau menolak terhadap implementasi kebijakan karena konflik kepentingan maka implementasi kebijakan akan menghadapi kendala yang serius.

Bentuk penolakan dapat bermacammacam seperti yang dikemukakan Edward III tentang "zona ketidakacuhan" dimana para pelaksana kebijakan melalui keleluasaanya (diskresi) dengan cara yang halus menghambat implementasi kebijakan dengan cara mengacuhkan, menunda dan tindakan penghambatan lainnya.Menurut pendapat Van Metter dan Van Horn dalam Agustinus (2006:162):"sikap penerimaan atau penolakan dari agen pelaksana kebijakan sangat mempengaruhi keberhasilan atau kegagalan implementasi kebijakan publik. Hal ini sangat mungkin terjadi karena kebijakan yang dilaksanakan bukanlah hasil formulasi warga setempat yang mengenal betul permasalahan dan persoalan yang mereka rasakan. Tetapi kebijakan publik biasanya bersifat top down yang sangat mungkin para pengambil keputusan tidak mengetahui bahkan tak mampu menyentuh kebutuhan, keinginan atau permasalahan yang harus diselesaikan".

Menurut Agustino (2006:157); "komunikasi merupakan salah-satu variabel penting yang mempengaruhi implementasi kebijakan publik, komunikasi sangat menentukan keberhasilan pencapaian tujuan dari implementasi kebijakan publik". Implementasi yang efektif akan terlaksana, jika para pembuat keputusan mengetahui mengenai apa yang akan mereka kerjakan. Infromasi yang diketahui para pengambil keputusan hanya bisa didapat melalui komunikasi yang baik. Terdapat tiga indikator yang dapat digunakan dalam mengkur keberhasilan variabel komunikasi. Edward III dalam Agustino (2006:157-158) mengemukakan tiga variabel tersebut yaitu: Transmisi. Penyaluran komunikasi yang baik akan dapat menghasilkan suatu implementasi yang baik pula. Seringkali terjadi masalah dalam penyaluran komunikasi yaitu adanya salah pengertian (miskomunikasi) yang disebabkan banyaknya tingkatan birokrasi yang harus dilalui dalam proses komunikasi, sehingga apa yang diharapkan terdirtorsi di tengah jalan. Kejelasan. Komunikasi yang diterima oleh pelaksana kebijakan (street-level-bureaucrats) harus jelas dan tidak membingungkan atau tidak ambigu/mendua. Konsistensi. Perintah yang diberikan dalam pelaksanaan suatu komunikasi harus konsisten dan jelas untuk ditetapkan atau dijalankan. Jika perintah yang diberikan sering berubah-ubah, maka dapat menimbulkan kebingungan bagi pelaksana di lapangan.

Berdasarkan hasil penelitian Edward III yang dirangkum dalam Winarno $(2005: 127)$ Terdapat beberapa hambatan umum yang biasa terjadi dalam transmisi komunikasi yaitu:Pertama, terdapat pertentangan antara pelaksana kebijakan dengan perintah yang dikeluarkan oleh pembuat kebijakan. Pertentangan seperti ini akan mengakibatkan distorsi dan hambatan yang langsung dalam komunikasi kebijakan. Kedua, informasi yang disampaikan melalui berlapis-lapis hierarki birokrasi. Distorsi komunikasi dapat terjadi karena panjangnya rantai informasi yang dapat mengakibatkan bias informasi. Ketiga, masalah penangkapan informasi juga diakibatkan oleh persepsi dan ketidakmampuan para pelaksana dalam memahami persyaratan-persyaratan suatu kebijakan. Menurut Winarno (2005:128) Faktorfaktor yang mendorong ketidakjelasan informasi dalam implementasi kebijakan publik biasanya karena kompleksitas kebijakan, kurangnya konsensus mengenai tujuan-tujuan kebijakan publik, adanya masalah-masalah dalam memulai kebijakan yang baru serta adanya kecenderungan menghindari pertanggungjawaban kebijakan.Dalam mengelola komunikasi yang baik perlu dibangun dan dikembangkan saluran-saluran komunikasi yang efektif. Semakin baik pengembangan saluran- 
saluran komunikasi yang dibangun, maka semakin tinggi probabilitas perintah-perintah tersebut diteruskan secara benar.

Dalam kejelasan informasi biasanya terdapat kecenderungan untuk mengaburkan tujuan-tujuan informasi oleh pelaku kebijakan atas dasar kepentingan sendiri dengan cara mengintrepetasikan informasi berdasarkan pemahaman sendiri-sendiri. Cara untuk mengantisipasi tindakan tersebut adalah dengan membuat prosedur melalui pernyataan yang jelas mengenai persyaratan, tujuan, menghilangkan pilihan dari multi intrepetasi, melaksanakan prosedur dengan hati-hati dan mekanisme pelaporan secara terinci. Faktor komunikasi sangat berpengaruh terhadap penerimaan kebijakan oleh kelompok sasaran, sehingga kualitas komunikasi akan mempengaruhi dalam mencapai efektivitas implementasi kebijakan publik. Dengan demikian, penyebaran isi kebijakan melalui proses komunikasi yang baik akan mempengaruhi terhadap implementasi kebijakan. Dalam hal ini, media komunikasi yang digunakan untuk menyebarluaskan isi kebijakan kepada kelompok sasaran akan sangat berperan.

\section{METODE}

Menurut Sugiyono (2008:1) menyatakan bahwa : "metode penelitian pada dasarnya merupakan cara ilmiah untuk mendapatkan data dengan tujuan dan kegunaan tertentu ". Rakhmat (2001:21), mengatakan: "para ahli berbeda pendapat dalam mengklasifikasikan metode penelitian. Disini metode penelitian dikategorikan dalam lima macam : historis, deskriptif, korelasional, eksperimental, dan kuasi-eksperimental". Dalam melakukan penelitian, orang dapat menggunakan berbagai macam metode, dan sejalan dengan rancangan penelitian yang digunakan juga dapat bermacam-macam. Dalam penelitian ini penulis menggunakan rancangan penelitian dalam katagori penelitian deskriptif. Rakhmat (2001:24), "metode deskripif hanyalah memaparkan situasi atau pristiwa. Penelitian ini tidak mencari atau menjelaskan hubungan, tidak menguji hipotesis atau membuat prediksi". Selanjutnya Sugiyono
(2008:11) mengatakan : "penelitian diskriptif adalah penelitian yang dilakukan untuk mengetahui nilai variabel mandiri, baik dsatu variabel atau lebih (independen) tanpa membuat perbandingan, atau menghubungkan antara variabel satu dengan variabel yang lain". subjek penelitian atau sumber informasi dalam penelitian dikelompokan menjadi 2 (dua) yaitu implementor dan kelompok sasaran. Kelompok implementor terdiri dari : Kepala Dinas Perindustrian Perdagangan Koperasi dan UKM Kabupaten Sintang dan Kepala Satuan Polisi Pamong Praja Kabupaten Sintang. Sedangkan kelompok sasaran adalah Pedagang Kaki Lima (PKL) yang berjumlah 15 orang di Kecamatan Sintang.

Lokasi penelitian ini di Kecamatan Sintang Kabupaten Sintang. Dalam penelitaian ini prosedur penelitian yang peneliti lakukan adalah melakukan pengumpulan data secara langsung di lapangan dengan mengunakan teknik pengumpulan data : 1 . wawancara atau interview yang dilakukan oleh peneliti kepada pihak-pihak terkait dengan kebijakan penataan Pedagang Kaki Lima di Kecamatan Sintang Kabupaten Sintang;2. Observasi atau pengamatan yang dilakukan oleh peneliti terhadap berbagai objek yang sesuai dengan fokus atau aspek penelitian yang berhubungan dengan implementasi kebijakan penataan Pedagang Kaki Lima di Kecamatan Sintang Kabupaten Sintang;3. Studi Dokumentasi. Melalui teknik ini, peneliti berusaha memperoleh data-data melalui dokumen yang berhubungan dengan masalah penelitian yaitu menyangkut berbagai referensi yang berhubungan dengan kebijakan penataan Pedagang Kaki Lima di Kecamatan Sintang Kabupaten Sintang. instrumen penelitian yang peneliti gunakan dalam penelitian ini adalah pedoman wawancara dan panduan observasi.

Metode analisis data yang digunakan adalah analisis non statistik, dimana Pertama-tama data itu diseleksi atas dasar reabilitas dan validitasnya. Data yang telah lulus seleksi itu lalu diatur dalam tabel atau matriks agar memudahkan pengolahan selanjutnya.Sedangakan tahapan analisis data 
dilakukan 4 (empat) tahapan yaitu : 1.Tahap Persiapan, yaitu mengumpulkan data yang telah diolah, menyangkut kegiatan koordinasi, perencanaan dan faktor mempengaruhinya; 2.Tahap Penilaian Data, yaitu validitas, obyektivitas dan relibilitasi data dengan cara mengkatagorikan data dengan sistem pencatatan dan perbandingan;3.Tahap Interpretasi Data, yaitu memberikan interpretasi atau penafsiran terhadap data-data yang telah diseleksi untuk kemudian diuraikan atau dijabarkan dalam bentuk pertanyaan atau pun argumentasi;4.Tahap Penyimpulan, yaitu Tahap kesimpulan, yaitu merupakan tahap akhir dari analisis data, dimana peneliti memberikan keputusan akhir dari hasil penafsiran menyangkut implementasi kebijakan penataan Pedagang Kaki Lima di Kecamatan Sintang Kabupaten Sintang.

\section{HASIL PENELITIAN DAN PEMBAHASAN}

Kecamatan Sintang merupakan salah satu dari 14 kecamatan yang terdapat di Kabupaten Sintang. Kecamatan Sintang merupakan satusatunya kecamatan yang terletak pada posisi strategis, hal ini dikarenakan ibu kota Kecamatan Sintang merupakan ibukota Kabupaten Sintang yang secara geografis terletak di antara $0^{0} 09^{1}$ $0^{0} 02^{1}$ derajad Lintang Utara dan $111^{0} 21^{1}-111^{0} 36^{1}$ derajad Bujur Timur. Secara Administratif, batas wilayah Kecamatan Sintang adalah sebagai berikut : Sebelah Utara : berbatasan dengan Kecamatan Binjai Hulu dan berbatasan dengan Kecamatan Kelam Permai;Sebelah Selatan : berbatasan dengan Kecamatan Sungai Tebelian;Sebelah Timur : berbatasan dengan Kecamatan Dedai;Sebelah Barat : berbatasan denagan Kecamatan Tempunak. Kecamatan Sintang memiliki luas wilayah sebesar 277,05 Km2 atau sebesar 1,28\% dari luas Kabupaten Sintang. Seluruh wilayah Kecamatan Sintang berdasarkan data yang terdapat pada BPS Kabupaten Sintang Tahun 2015 diketahui bahwa jenis tanah yang terdapat di Kecamatan Sintang adalah berjenis aluvial dan tidak memiliki daerah perbukitan .Dari Kecamatan Sintang tersebut terbagi kedalam luas Kelurahan dan Desa yang terdapat di Kecamatan Sintang.
Kecamatan Sintang terdiri dari 10 (sepuluh) Kelurahan, 19 (sembilan belas) Desa, 26 Dusun, 208 RT dan 51 RW. Penduduk Kecamatan Sintang pada tahun 2013 berjumlah 65.939 jiwa yang terdiri dari laki-laki 33.464 jiwa dan perempuan 32.475 jiwa.

Kebijakan penataan Pedagang Kaki Lima di Kecamatan Sintang merupakan bagian dari kebijakan pembangunan Kabupaten Sintang. Berdasarkan hasil wawancara dengan subyek penelitian, kebijakan penataan pedagang kaki lima di lakukan oleh Pemerintah Daerah Kabupaten Sintang dalam rangka untuk mewujudkan kota sintang yang tertib, bersih, aman dan nyaman sesuai dengan rencana Tata Ruang Kabupaten Sintang.Dalam penataan Pedagang Kaki Lima di Kecamatan Sintang melalui instansi terkait telah melakukan berbagai upaya penertiban terhadap pedagang kaki lima di kota Sintang. Berdasarkan observasi peneliti dan wawancara dengan Kepada Dinas Perindustrian, Perdagangan, UKM dan Koperasi Kabupaten Sintang, diperoleh informasi bahwa keijakan yang telah di ambil oleh Pemerintah Kabupaten Sintang berkaitan dengan Pedagang Kaki Lima di Kecamatan Sintang meliputi kegiatan: Pendataan terhadap Pedagang Kaki Lima: melakukan pembinaan terhadap pedagang kaki lima dengan tentang aturan dengan arti penting ketertiban dan keamanan; melakukan penertiban dan penataan lokasi Pedagang Kaki Lima; melakukan pemindahan tempat usaha Pedagang Kaki Lima; pelakukan pembongkaran terhadap tempat usaha Pedagang Kaki Lima yang tidak sesuai dengan ketentuan yang berlaku.

Hasil penelitian menunjukkan, proses kegiatan penataan Pedagang Kaki Lima di Kecamatan Sintang meliputi beberapa tahapan. Tahapan pertama, yang diambil oleh Pemerintah Kabupaten Sintang adalah dengan mengoptimalkan komunikasi, tahapan kedua, Kegiatan pemebinaan terhadap Pedagang Kaki Lima, dan tahapan ketiga, adalah tindakan tegas berupa pembongkaran tempat usaha Pedagang Kaki Lima.Pelaksanaan kegiatan komunikasi dilakukan dengan melakukan kegiatan sosialisasi Peraturan Perundang- 
Undangan dan kebijakan Pemerintah Daerah Kabupaten Sintang yang berkaitan dengan pengeloalaan Pedagang Kaki Lima dan Tata Ruang Wilayah Kabupaten Sintang kepada para PKL yang terdapat di Kecamatan Sintang. Menurut Kepada Dinas Perindustrian, Perdagangan, UKM dan Koperasi Kabupaten Sintang, kegiatan sosialisasi kepada para Pedagang Kaki Lima yang merupakan target group adalah merupakan suatu kegaiatan yang harus dilakukan. Kegiatan sosialisasi dilakukan oleh Pemerintah Daerah Kabupaten Sintang dalam rangka memberikan pemahaman dan pengertian kepada para Pedagang Kaki Lima di Kecamatan Sintang.

Kegiatan sosialisasi peraturan perundangungangan yang berhubungan dengan Pedagang Kaki Lima dilaksanakan oleh Dinas Perindustrian, Perdagangan, UKM dan Koperasi Kabupaten Sintang yang berkerjasama dengan instansi terkait seperti Bagian Hukum Setda Sintang, Sappol PP Kabupaten Sintang dan Pemerintah Kecamatan Sintang. Pelaksanaaan Sosialisasi dilakukan dalam dua bentuk: pertama, penyebaran informasi melalui media massa seperti koran dan radio dan media lainya seperti spanduk dan lain -lain; dan kedua, dilakukan dengan cara melakukan penyuluhan langsung kepada Pedagang Kaki Lima. Tempat sosialisasi yang dilakukan oleh Dinas Perindustrian, Perdagangan, UKM dan Koperasi Kabupaten Sintang terhadap Pedagang Kaki Lima dilaksanakan dibeberapa tempat, khusus sosialisasi dalam bentuk penyuluhan dilaksanakan dengen bebeberapa cara: pertama, mendatangi secara langgsung PKL tersebut secara satu persatu denagn menyampaikan peraturan perundangungdangan yang ada; kedua, dengan mengumpulkan para PKL pada tempat yang telah di tentukan seperti pasar junujung buih dan pasar masuka. Kegiatan komunikasi juga dilakukan oleh Pemerintah Daerah Kabupaten Sintang dalam bentuk pembinaaan terhadap Pedagang Kaki Lima dengan melakukan pendekatan secara persuasif agar Pedagang Kaki Lima secara sadar atau suka rela mau mentaati kebijakan yang telah diambil oleh Pemerintah Daerah Kabupaten Sintang. Apabila pendekatan sesara persuasif tidak dapat dijalankan, maka upaya Pemerintah Daerah Kabupaten Sintang dalam penataan Pedagang Kaki Lima di Kecamatan Sintang adalah dengan kegiatan yang secara lebih represif berupa tindakan tegas pembongkaran bangunan atau tempat usaha Pedagang Kaki Lima tentunya didasarkan atas dasar ketentuan peraturan perUndang-Undangan yang berlaku.

Upaya Pemerintah Daerah Kabupaten Sintang dalam penataan Pedagang Kaki Lima di Kecamatan Sintang, terutama berkaitan dengan pembongkaran bangunan atau tempat tinggal pedagang kaki lima didasarkan atas Peraturan Daerah Kabupaten Sintang No 30 Tahun 2006 Tentang Retribusi Pelayanan Usaha Pedagang yang di tindak lanjuti Dengan Surat Bupati Sintang Nomor 510/296/Disperindag/2007 Perihal Penertiban Tempat Usaha dan Ijin Mendirikan Bangunan (IMB) Kabupaten Sintang dan Surat Bupati Sintang Nomor 510/324/Disperindag/2007 perihal pemberitahuan ke - 2 Penertiban Tempat Usaha. Kebijakan Pemerintah Daerah Kabupaten Sintang dalam penataan Pedagang Kaki Lima di Kecamatan Sintang, menurut Kepala Dinas Perindustrian, Perdagangan, Koperasi dan UKM Kabupaten Sintang, belum bisa dilaksanakan secara efektif, terutama berkaitan dengan kebijakan pembongkaran bangunan tempat usaha Pedagang Kaki Lima dan upaya untuk memindahkan tempat usaha Pedagang Kaki Lima ke tempat yang di tentukan oleh Pemerintah Daerah Kabupaten Sintang. Belum efektifnya kebijakan penataan Pedagang Kaki Lima yang dilakukan oleh pemerintah daerah Kabupaten Sintang juga sesuai dengan observasi peneliti terhadap Pedagang Kaki Lima yang melakukan usahanya di tempat-tempat yang dilarang oleh Pemeritah Daerah Kabupaten Sintang, seperti yang terlihat dikawasan Pasar Sungai Durian Kelurahan Kapuas Kanan Hulu.

Tidak efektifnya penataan Pedagang Kaki Lima yang dilakukan Pemerintah Daerah Kabupaten Sintang dikarenakan : Pertama, aktivitas Pedagang Kaki Lima dilakukan di Kecamatan Sintang sudah dilakukan dalam kurun 
waktu yang lama; kedua, jumlah Pedagang Kaki Lima yang terdapat di Kecamatan Sintang jumlahnya sudah banyak dan selalu bertambah dari waktu kewaktu, sementara lokasi tempat usaha yang terbatas; dan Ketiga, tempat usaha yang dijadikan lokasi alternatif untuk memindahkan Pedagang Kaki Lima berusaha di situ kurang strategis, sehingga para Pedagang Kaki Lima menolak untuk dipindahkan kelokasi yang suadah disediakan oleh Pemerintah Daerah Kabupaten Sintang tersebut. Berkaitan dengan strategi yang di lakukan oleh Pemerintah Daerah Kabupaten Sintang dalam upaya Pemerintah Daerah Kabupaten Sintang dalam penataan Pedagang Kaki Lima di Kecamatan Sintang dapat dikatakan belum efektif. Belum efektifnya strategi yang dilakukan oleh Pemerintah Daerah Kabupaten Sintang dalam penataan Pedagang Kaki Lima dapat dilihat dari keberadaan Pedagang Kaki Lima yang masih melakukan aktivitas usahanya di tempat-tempat yang dilarang oleh Pemerintah Kabupaten Sintang. Komunikasi yang baik akan memberikan informasi yang baik, ini akan berpengaruh dalam pengambilan keputusan, karena pelaksanaan koordinasi dilakukan dalam rangka pengambilan keputusan. Kalau informasi yang menjadi bahan pertimbangan dalam pengambilan keputusan kurang baik. Maka hasil keputusanpun akan berdampak kurang baik pula, demikian pula sebaliknya. Jadi dengan adanya komunikasi ini diharapkan akan lebih memberikan nilai bobot dari hasil keputusan yang dihasilkan. Komunikasi merupakan dasar bagi semua interaksi manusia, termasuk di dalamnya implementasi kebijakan. Oleh sebab itu komunikasi mempunyai peran dominan dalam kehidupan manusia. Hasan (2005:22) fungsi komunikasi adalah : "1) mencapai pengertian satu sama lain, 2) membina kepercayaan, 3) mengkoordinir tindakan, 4) merencanakan strategi, 5) melakukan pembagian kerja, 6) melakukan aktivitas kelompok, dan 7) berbagi rasa". Dengan demikian dapat dikatakan memberikan kemudahan, kelancaran dan keteraturan dalam rangka implementasi kebijakan penataan Pedagang Kaki Lima di Kecamatan Sintang. Manakala komunikasi ini memberikan informasi yang akurat, lengkap dan mudah dipahami. Namun dilain pihak komunikasi ini juga menjadi faktor penghambat dalam implementasi kebijakan penataan Pedagang Kaki Lima di Kecamatan Sintang, manakala komunikasi ini kurang didukung oleh suatu informasi yang tepat dan relevan dalam rangka implementasi kebijakan.

Dari hasil penelitian diketahui bahawa dalam implementasi kebijakan Penataan Pedagang Kaki Lima di Kecamatan Sintang, Pemerintah Daerah Kabupeten Sintang telah melakukan dua bentuk komunikasi kepada PKL. Bentuk pertama adalah komunikasi yang bersifat persuasif yang dilakukan dengan kegiatan sosialisasi dan pembinaan Pedagang Kaki Lima, dan bentuk kedua komunikasi yang dilakukan secara represif yang menggunakan pola-pola aksi seperti pembongkaran lapak atau kios para Pedagang Kaki Lima yang beraktifitas di lokasi yang dilarang Pemerintah Daerah Kabupeten Sintang. Dari hasil penelitian tersebut, jika di hubungkan dengan teori Edward III, dapat dikatakan bahwa faktor komunikasi dalam implementasi kebijakan Penataan Pedagang Kaki Lima di Kecamatan Sintang adalah merupakan faktor yang bersifat pendukung dalam implementasi kebijakan Penataan Pedagang Kaki Lima di Kecamatan Sintang. hal ini sejalan dengan pemikiran Edward III yang mengatakan informasi kebijakan perlu disampaikan kepada pelaku kebijakan agar pelaku kebijakan dapat mengetahui, memahami apa yang menjadi isi, tujuan, arah, kelompok sasaran kebijakan agar apa yang menjadi tujuan dan sasasaran kebijakan dapat dicapai sesuai dengan yang diharapkan.

Informasi merupakan faktor penting bagi pelaksanaan kebijakan. Ada dua bentuk informasi yaitu informasi mengenahi bagaimana cara menyelesaikan kebijakan/program serta bagi pelaksana harus mengetahui tindakan apa yang harus dilakukan dan informasi tentang data pendukung kepetuhan kepada peraturan pemerintah dan undang-undang. Kenyataan dilapangan bahwa tingkat pusat tidak tahu kebutuhan yang diperlukan para pelaksana di lapangan. Kekurangan informasi/pengetahuan 
bagaimana melaksanakan kebijakan memiliki konsekuensi langsung seperti pelaksana tidak bertanggungjawab, atau pelaksana tidak ada di tempat kerja sehingga menimbulkan inefisien. Dalam pelaksanaan penatan Pedagang Kaki Lima di Kecamatan Sintang, tidak terlepas dari dukungan ketersedian sumber daya kebiajakan. Berdasarkan hasil penlitian dilapangan dapat diketahui bahwa suber daya kebiajakn yang mempengaruhi implementasi kebiajakan penatan Pedagang Kaki Lima di Kecamatan Sintang adalah meliputi : sumber daya aparatur pelaksana kebijakan, sumber daya peralatan dan sumber daya anggaran.Sumber daya aparatur pelaksana kebijakan dapat dikatakan merupakan salah satu faktor pendukung implemantasi kebiajakan penataan Pedagang Kaki Lima di Kecamatan Sintang, hal ini dapat dilihat dari kesiapan aparatur pelaksana kebijakan, yang baik secara kuantitas maupun secara kualitas telah sesuai kompetensinya untuk memgimplentasikan kebijakan penataan Pedagang Kaki Lima di Kecamatan Sintang. Berkaitan dengan ketersedian sumber daya manusia aparatur pelaksana implementasi kebijakan penataan Pedagang Kaki Lima di Kecamatan Sintang yaitu berhubungan dengan Dinas Perindustrian, Perdagangan, Koperasi dan UKM Kabupaten Sintang dan Satuan Polisi Pamong Praja Kabupaten Sintang dapat dilihat pada tabel 3 dan tabel 4. tentang komposisi pegagawai berdasarkan jumlah, status kepegawaian dan tingkat pendidikan di Dinas Dinas Perindustrian, Perdagangan, Koperasi dan UKM Kabupaten Sintang Tahun 2015 berikut ini :

Tabel 3. Komposisi Pegagawai Berdasarkan Jumlah, Status Kepegawaian Dan Tingkat Pendidikan Di Dinas Dinas Perindustrian, Perdagangan, Koperasi dan UKM Kabupaten Sintang Tahun 2015

\begin{tabular}{|l|l|l|c|}
\hline No & Status Kepegawaian & \multicolumn{1}{|c|}{ Tingakat Pendidikan } & Jumlah (Orang) \\
\hline \multirow{4}{*}{1.} & \multirow{3}{*}{ Pegawai Negeri Sipil } & Pasca Sarjana (S2) & 10 \\
\cline { 3 - 4 } & & Sarjana (S1) & 17 \\
\cline { 3 - 4 } & & Dipeloma & 3 \\
\cline { 3 - 4 } & & SMA & 12 \\
\cline { 3 - 4 } & & SMP & 3 \\
\hline \multirow{2}{*}{2.} & \multirow{2}{*}{ Pegawai Honorer } & Sarjana (S1) & 1 \\
\cline { 3 - 4 } & & Dipeloma & 1 \\
\cline { 3 - 4 } & & SMA & 6 \\
\hline \multicolumn{2}{|c|}{ Jumlah } & 53 \\
\hline
\end{tabular}

Sumber : Dinas Dinas Perindustrian, Perdagangan, Koperasi dan UKM Kabupaten Sintang, Maret 2016

Tabel 4. Komposisi Pegagawai Berdasarkan Jumlah, Status Kepegawaian Dan Tingkat Pendidikan Di Satuan Polisi Pamong Praja Kabupaten Sintang Tahun 2015

\begin{tabular}{|l|l|l|c|}
\hline $\mathbf{o}$ & Status Kepegawaian & \multicolumn{1}{|c|}{ Tingakat Pendidikan } & Jumlah (Orang) \\
\hline \multirow{4}{*}{ Pegawai Negeri Sipil } & Pasca Sarjana (S2) & 6 \\
\cline { 3 - 4 } & Sarjana (S1) & 19 \\
\cline { 2 - 4 } & SMA & 33 \\
\cline { 2 - 4 } & SMP & 2 \\
\hline \multirow{2}{*}{ Pegawai Honorer } & Sarjana (S1) & 1 \\
\cline { 3 - 4 } & & SMA & 13 \\
\hline \multicolumn{2}{|l|}{ Jumlah } & 74 \\
\hline
\end{tabular}

Sumber : Kantor Satuan Polisi Pamong Praja Kabupaten Sintang, Maret 2016

Berdasarkan data kepegawaian pada tabel 3 dan tabel 4 tersebut, dapat dikatakan jika ditinjau dari segi kualitas dan kuantitas Sumber Daya Manusia yang terdapat di dua instansi pelaksana 
atau implementor kebijakan penataan Pedantang Kaki Lima di kecamatan Sintang dalam hal ini Dinas Dinas Perindustrian, Perdagangan, Koperasi dan UKM Kabupaten Sintang dan Satuan Polisi Pamong Praja Kabupaten Sintang dapat dikatakan sudah memadai. Sejalan dengan hal tersebut, hasil wawancara peneliliti dengan Kepada Dinas Perindustrian, Perdagangan, UKM dan Koperasi Kabupaten Sintang, mengatakan bahwa secara kualitas dan kuantitas dengan Dinas Perindustrian, Perdagangan, UKM dan Koperasi Kabupaten Sintang sebagai bagian dari implementor kebijakan penatan Pedagang Kaki Lima di Kabupaten Sintang sudah siap dan dapat melaksanakan tugas dan fungsi sesuai dengan ketentuan yang berlaku. Jjumlah personil atau pegawai di Satuan Polisi Pamong Praja Kabupaten Sintang sudah siap dan mampu melaksanakan penegakan peraturan perundang-undangan khususnya peraturan daerah yang berhubungan dengan penataan Pedagang Kaki Lima di Kabupaten Sintang umumnya dan Kecamatan Sintang sebagai ibukota Kabupaten Sintang khusunya.

Sumber daya yang menjadi kendala dalam kebijakan penataan PKL di Kecamatan Sintang berkaitan dengan sumber daya peralatan dan sumber daya anggaran. Hasil penelitian dilapangan menunjukan bahwa sumber daya peralatan yaitu berhubungan dengan tempat atau fasilitas yang dapat disediakan oleh Pemerintah Kabupaten Sintang guna penempatan PKL masih terbatas atau belum sesuai dengan kebutuhan. Kenyataan ini dapat terlihat dari lokasi atau tempat yang dapat disediakan oleh Pemerintah Kabupaten Sintang untuk relokasi PKL di Kecamatan Sintang hanya 2 (dua) lokasi saja dan hanya mampu menampung 100 PKL, sedangkan jumlah PKL yang menempati lokasi yang di larang di Kecamatan Sintang pada tahun 2014 terdapat 290 orang yang tersebar di 13 lokasi. Berdasarkan hasil observasi di lapangan, jika melihat keberadaan PKL yang berjumlah 290 orang yang menempati lokasi yang dilarang, apabila direlokasikan dengan melihat daya tampung tempat relokasi yang di sediakan oleh Pemerintah Kabupaten Sintang, paling tidak di perlukan 3 (tiga) lokasi baru yang semestinya di siapakan oleh Pemerintah Kabupaten Sintang untuk relokasi PKL yang terdapat di Kecamatan Sintang. Pemerintah Kabupaten Sintang telah merencanakan lokasi baru untuk penempatan PKL yang selama ini beraktivitas atau berusaha pada tempat-tempat yang dilarang oleh Pemerintah Kabupaten Sintang. Belum dapat terialisasinya rencana pembangunan atau penyediaan lokasi tersebut di sebabakan terkendala dengan persoalan terbatasnya anggaran. Dimana anggaran yang diperlukan cukup besar terutama berkaitan dengan pembebasan lahan dan pembangunan gedung dan fasilitas pendukung lainnya. Pada dasarnya mereka tidak keberatan apabila adanya relokasi tempat usaha bagi mereka, dengan persyaratan : pertama, tempat tersebut memenuhi syarat bagi mereka untuk melakukan aktivitas usaha; kedua, biaya sewa atau hak guna usaha terjangkau bagi mereka. Sumber daya memiliki peranan penting dalam implementasi kebijakan. Edward III dalam Widodo (2011:98) mengemukakan bahwa: bagaimanapun jelas dan konsistensinya ketentuan-ketentuan dan aturanaturan serta bagaimanapun akuratnya penyampaian ketentuan-ketentuan atau aturanaturan tersebut, jika para pelaksana kebijakan yang bertanggung jawab untuk melaksanakan kebijakan kurang mempunyai sumber-sumber daya untuk melaksanakan kebijakan secara efektif maka implementasi kebijakan tersebut tidak akan efektif. Sumber daya di sini berkaitan dengan segala sumber yang dapat digunakan untuk mendukung keberhasilan implementasi kebijakan.tidak menjadi masalah bagaimana jelas dan konsisten implementasi program dan bagaimana akuratnya komunikasi dikirim. Jika personel yang bertanggungjawab untuk melaksanakan program kekurangan sumberdaya dalam melakukan tugasnya. Komponen sumberdaya ini meliputi jumlah staf, keahlian dari para pelaksana, informasi yang relevan dan cukup untuk mengimplementasikan kebijakan dan pemenuhan sumber-sumber terkait dalam pelaksanaan program, adanya kewenangan yang menjamin bahwa program dapat diarahkan kepada 
sebagaimana yamg diharapkan, serta adanya fasilitas-fasilitas pendukung yang dapat dipakai untuk melakukan kegiatan program seperti dana dan sarana prasarana. Berkaitan dengan Sumber Daya Manusia implementor dalam implementasi kebijakan penataan Pedagang Kaki Lima di Kecamatan Sintang, berdasrkan hasil penelitian dapat dikatakan sudah mememadai, baik ditinjau dari segi kuantitas maupun kualitasnya, sehingga dapat dikatakan merupakan faktor pendukung implementasi kebijakan penataan Pedagang Kaki Lima di Kecamatan Sintang. Apabila Sumberdaya manusia yang tidak memadahi (jumlah dan kemampuan) berakibat tidak dapat dilaksanakannya program secara sempurna karena mereka tidak bisa melakukan pengawasan dengan baik. Jika jumlah staf pelaksana kebijakan terbatas maka hal yang harus dilakukan meningkatkan skill/ kemampuan para pelaksana untuk melakukan program. Untuk itu perlu adanya manajemen SDM yang baik agar dapat meningkatkan kinerja program.

Sedangkan sumber daya berupa peralatan atau fasilitas terutama berhubungan dengan penyediaan tempat atau lokasi usaha bagi Pedagang Kaki Lima di Kecamatan Sintang masih terbatas dan belum sesuai dengan kebutuhan. Begitu pula dengan sumber daya finansial atau anggaran dalam penataan Pedagang Kaki Lima di Kecamatan Sintang masih terbatas, dan kedua sumber daya ini dapat dikatakan merupakan faktor kendala dalam implementasi kebijakan penataan Pedagang Kaki Lima di Kecamatan Sintang. Dalam implementasi kebijakan publik semestinya, ketersediaan sumber daya anggaran dan peralatan adalah merupakan persyaratan mutlak untuk suksesnya implementasi kebijakan tersebut. peralatan atau fasilitas yang diperlukan untuk melaksanakan kebijakan/program harus terpenuhi seperti kantor, peralatan, serta dana yang mencukupi. Tanpa fasilitas ini mustahil program dapat berjalan. Apabila mengacu kepada pendapat para ahli yang mengatakan : setiap kantor atau organisasi akan dapat bekerja dengan baik, apabila diberikan perlengkapan material yang memadai, dan digunakan seefisien mungkin dengan jangka waktu sesuai dengan umur seharusnya dari perlengkapan yang bersangkutan. Dengan demikian dapat dikatakan, sarana dan prasarana merupakan hal yang penting karena jika tidak dipenuhi maka para pegawai akan malas dan kurang bergairah untuk bekerja, sehingga tujuan oraganisasi tidak akan tercapai.

Berhasil atau tidaknya implementasi kebijakan penataan Pedagang Kaki Lima di Kecamatan Sintang, salah satu faktor penentunya adalah berkaitan dengan disposisi atau sikap aparatur pelaksana kebijakan (implementor). Sikap implemntor ini berkaitan dengan komitmen, kemauan, dan keinginan dari implementor untuk mewujudkan pencapaian tujuan kebijakan publik tersebut.Pemerintah Kabupaten Sintang secara serius dan memiliki komitmen yang kuat untuk penataan Pedagang Kaki Lima terutama yang terdapat di Kecamatan Sintang. Ada 3 (tiga) alasan yang menjadi dasar dari komitmen Pemerintah Kabupaten Sintang dalam penataan Pedagang Kaki Lima di Kecamatan Sintang. Alasan pertama, Kecamatan Sintang merupakan satu-satunya kecamatang yang terdapat di ibukota Kabupaten Sintang dan sekaligus merupakan ibukota Kabupaten Sintang. Sebagai ibukota Kabupaten, sudah sepantasnya Kecamatan Sintang memiliki penataan wilayah yang lebih baik sebagai rujukan atau tulok ukur bagi pembangunan dan pengembangan penataan wilayah bagi kecamatankecematan lainnya yang terdapat di Kebupaten Sintang. Alasan kedua, penataan Pedagang Kaki Lima di Kecamatan Sintang merupakan suatu keharusan, yang merupakan wujud nyata dalam mendukung konsep Sintang Kota BERSEMI ( bersih, Sehat, Menawan dan Indah). Alasan ketiga, adalah dalam rangka mempersiapkan Kecamatan Sintang sebagai Kota Maju yang tidak hanya sebagai pusat Pemerintahan (Provinsi dan Kota) malainkan sebagai pusat Perdagangan, Pendidikan dan Wisata. Apabila melihat kenyatan di lapangan, maka dapat dikatakan Pemerintah Kabupaten Sintang sangat serius dalam penatan Pedagang Kaki Lima, hal ini juga terlihat dari berbagai upaya 
kebijakan yang diambil oleh Pemerintah Kabupaten Sintang. Kepala Satpol PP Kabupaten Sintang, mengatakan upaya kebijakan tersebut, baik menyangkut regulasi kebijakan, maupun upaya persuasif dan represif pembinaan para Pedagang Kaki Lima yang terdapat di Kecamatan Sintang. Salah satu faktor yang mempengaruhi efektivitas implementasi kebijakan adalah sikap implementor. Jika implemetor setuju dengan bagian-bagian isi dari kebijakan maka mereka akan melaksanakan dengan senang hati tetapi jika pandangan mereka berbeda dengan pembuat kebijakan maka proses implementasi akan mengalami banyak masalah.

Ada tiga bentuk sikap atau respon implementor terhadap kebijakan ; kesadaran pelaksana, petunjuk atau arahan pelaksana untuk merespon program kearah penerimaan atau penolakan, dan intensitas dari respon tersebut. Para pelaksana mungkin memahami maksud dan sasaran program namun seringkali mengalami kegagalan dalam melaksanakan program secara tepat karena mereka menolak tujuan yang ada didalamnya sehingga secara sembunyi mengalihkan dan menghindari implementasi program. Disamping itu dukungan para pejabat pelaksana sangat dibutuhkan dalam mencapai sasaran program. Dukungan dari pimpinan sangat mempengaruhi pelaksanaan program dapat mencapai tujuan secara efektif dan efisien. Wujud dari dukungan pimpinan ini adalah menempatkan kebijakan menjadi prioritas program, penempatan pelaksana dengan orang-orang yang mendukung program, memperhatikan keseimbangan daerah, agama, suku, jenis kelamin dan karakteristik demografi yang lain. Disamping itu penyediaan dana yang cukup guna memberikan insentif bagi para pelaksana program agar mereka mendukung dan bekerja secara total dalam melaksanakan kebijakan atau program. Dakam implementasi kebijakan penataan Pedagang Kaki Lima di Kecamatan Sintang, sikap implementor dapat dikatakan merupakan faktor pendukung yang berperan besar. Hal ini dapat terlihat dari komitmen dan kerja keras dari para implementor untuk menjalankan Pemerintah Daerah Kabupaten Sintang Nomor 9
Tahun 2011 Tentang Penataaan Pedagang Kaki Lima di Kabupaten Sintang, sebagai regulasi hukum yang menjadi petunjuk teknis bagi para implentor untuk melakukan penataan terhadap Pedagang Kaki Lima yang terdapat di Kecamatan Sintang. Formulasi kebijakan penataan Pedagang Kaki Lima, Pemerintah Daerah Kabupaten Sintang melibatkan semua Steakholders yang ada termasuk para Pedagang Kaki Lima. Keterlibatan Pedagang Kaki Lima dalam perumusan kebijakan yang akan dibuat oleh Pemerintah Daerah Kabupaten Sintang, menurut subyek penelitian adalah dalam rangka untuk memberikan kedasaran kepada Pedagang Kaki Lima dalam melakukan aktivitas usahanya agar sesuai dengan arah kebijakan yang telah ditetapkan oleh Pemerintah Daerah Kabupaten Sintang. Dalam perumusan kebijakan berkaitan dengan penataan Pedagang Kaki Lima di Kecamatan Sintang, tentunya dilakukan dengan berbagai strategi kebijakan. Berdasarkan hasil wawancara yang peneliti lakukan dengan Kepala Satpol PP Kabupaten Sintang, strategi yang di tetapkan oleh Pemerintah Kabupaten Sintang dalam penataan Pedagang Kaki Lima adalah pertama melakukan koordinasi lintas instansi yang terkait dengan penataan pedagang kaki lima yaitu, BAPPEDA Kabupaten Sintang, Bagian Tata Pemerintah Kabupaten Sintang, Dinas Perindustrian Kabupaten Sintang, Dinas Perhubungan Kabupaten Sintang, Kantor Kebersihan dan Kebakaran Kabupaten Sintang, Camat Sintang, Lurah-lurah yang berada dalam di Kecamatan Sintang dan LSM; dan strategi yang kedua yang dilakukan oleh Pemerintah Daerah Kabupaten Sintang dalam penataan Pedagang Kaki Lima adalah dengan cara melakukan pendekatan dan pembinaan lansung terhadap Pedagang Kaki Lima.

Startegi pendekatan kepada PKL dilakukan dalam rangka untuk meningkatkan partisipasi PKL. Pertisipasi Pedagang Kaki Lima merupakan salah satu masukan pembangunan guna mendukung cita-cita pembangunan, partisipasi merupakan hak dan kewajiban masyarakat dalam hal ini PKL dalam menyukseskan jalannya pembangunan. Dalam penataan Pedagang Kaki 
Lima yang ada di Kecamatan Sntang, tentunya memerlukan partisipasi atau keterlibatatan para Pedagang Kaki Lima. Hasil penelitian di lapangan, menunjukan bahwa partisipasi Pedagang Kaki Lima diperlukan dalam perumusan kebijakan dan implementasi kebijakan penataan Pedagang Kaki Lima. Partisipasi PKL menurut implementor kebijakan, diperlukan dengan alasan, Pedagang Kaki Lima adalah merupakan sasaran atau objek dari kebijakan penataan, dan disisi yang lain para Pedagang Kaki Lima adalah merupakan subyek atau individu yang mempunyai kepentingan, harapan, dan gagasan-gagasan dalam suatu komonitas sosial.

Partisipasi dari Pedagang Kaki Lima dalam perumusan dan pelaksanaan kebijakan belum optimal atau belum semuanya aktif. Menurut subyek penelitian, partisipasi Pedagang Kaki Lima ini masih berupa sumbang saran dan protes berkaitan dengan tempat yang layak berkaitan dengan relokasi untuk mereka melakukan aktivitas jusahanya. sumbang saran yang di sampaikan oleh para Pedagang Kaki Lima lebih merupakan suatu keinginan dari Pedagang Kaki Lima untuk bisa berjualan atau melakukan aktivitas usaha-usahanya di tempat strategis seperti dipusat-pusat perbelanjaan yang dikunjungi atau dilewati oleh konsumen atau masyarakat, sedangkan protes yang dilakukan pedagang kaki lima kepada Pemerintah Daerah Kabupaten Sintang untuk memindahkan tempat usaha mereka pada tempat yang telah ditetapkan oleh Pemerintah Daerah Kabupaten Sintang. Tingkat partisipasi Pedagang Kaki Lima dalam pelaksanaan kebijakan penataan Pedagang Kaki Lima yang dilakukan Oleh Pemerintah Daerah Kabupaten Sintang masih dalam bentuk partisipasi dalam tuntuan, sedangkan partisipasi dalam bentuk dukungan terhadap kebijakan penataan Pedagang Kaki Lima yang dilakukan oleh Pemerintah Daerah Kabupaten Sintang belum begitu kelihatan.Membahas badan pelaksana suatu kebijakan, tidak dapat dilepaskan dari struktur birokrasi. Struktur birokrasi adalah karakteristik, norma-norma, dan pola-pola hubungan yang terjadi berulang-ulang dalam badan-badan eksekutif yang mempunyai hubungan baik potensial maupun nyata dengan apa yang mereka miliki dalam menjalankan kebijakan.

Koordinasi merupakan faktor yang sangat dominan di dalam kehidupan suatu organisasi. Oleh karena itu, koordinasi harus secara terus-menerus ditingkatkan dalam rangka mencapai tujuan organisasi secara optimal. Sebagaimana diketahui bahwa setiap individu-individu dan organisasi memiliki tujuan. Untuk mencapai tujuannya, orang-orang atau bagian-bagian yang tergabung di dalam organisasi dan pihak-pihak yang terkait dengan pencapaian tujuan, melakukan koordinasi. Pada kegiatan yang lebih luas dan kompleks koordinasi ini semakin menjadi penting, mengingat dalam era globalisasi tidak satupun unit kerja atau organisasi yang dapat mencapai tujuan tanpa melakukan koordinasi dengan unit kerja yang lain. Koordinasi adalah salah satu bentuk hubungan kerja yang memiliki karakteristik khusus. Kadarmo, Suganda dan Supono (2001:6) "karakteristiknya antara lain harus adanya integrasi serta sinkronisasi atau adanya keterpaduan, keharmonisan, serta arah yang sama". Pentingnya koordinasi ini agar organisasi dapat menciptakan efektifitas dan efisiensi. Hal ini berarti bahwa tujuan organisasi dapat tercapai serta dalam pencapaiannya dimanfaatkan semua sumber daya secara hemat dan ekonomis.

Dengan berpedoman pada ketentuan tersebut, Kadarmo, Suganda dan Supono (2001:11) menyatakan koordinasi dalam suatu organisasi dimaksudkan agar organisasi dapat :1). Membangkitkan kesadaran pada setiap orang dan setiap manajer bahwa kedudukan, fungsi dan pekerjaannya berkaitan dengan kedudukan, fungsi, dan pekerjaan pihak lainnya, sehingga merasa bahwa kedudukan, fungsi, dan pekerjaannya tidak lepas dari yang lain; 2). Memelihara dan mengembangkan saling pengertian di antara para pejabat di dalam organisasi, sehingga dapat menumbuhkan kesadaran bahwa dirinya memerlukan bantuan pihak lain dan sebaliknya dirinya memerlukan bantuan pihak lain, sehingga timbul semangat kerjasama dalam pelaksanaan 
tugas masing-masing; 3). Memelihara dan mengembangkan semangat persatuan pada setiap orang, karena tugas dirinya dan tugas pihak lain di dalam organisasi merupakan bagian-bagian dari tugas yang lebih besar, sehingga setiap tugas berkaitan erat dan pelaksanaannya perlu saling mendukung; 4). Menumbuhkan sikap para pelaksana untuk mematuhi peraturan yang mengatur hubungan kerja antar unit organisasi dan antar organisasi dalam suatu sistem baik pemerintahan maupun perusahaan.

Struktur birokrasi dalam implementasi kebijakan Penataan Pedagang Kaki Lima di Kecamatan Sintang telah melibatkan berbagai instasi terkait dan berbagai stakeholder yang berhubungan dengan Penataan Pedagang Kaki Lima di Kecamatan Sintang. Hal ini terlihat dari berbagai kegiatan koordinasi yang dilakukan. Rancangan proses kebijakan yang sudah disusun perlu disosialisasikan kepada para stakeholder. Langkah sosialisasi sengaja dilakukan sebelum rancangan menjadi lebih matang sebagai sebuah prosedur pelayanan yang baku. Pendekatan seperti ini memang sengaja dipilih agar masih terbuka peluang lebar-lebar bagi para stakeholder untuk dapat ikut serta dalam implementasi kebijakan publik. Implementor kebijakan penataan Pedagang Kaki Lima berasal dari beberapa instansi yang berbeda yang terdapat di Pemerintah Daerah Kabupaten Sintang. Situasi semacam ini menuntut adanya koordinasi lintas instansi yang terkait, sehingga secara keseluruhan proses implementasi kebijakan selalu berjalan tertib dan lancar. Koordinasi dilakukan dengan cara dialog agar diperoleh komitmen yang murni. Hasil koordinasi berupa kecepatan pasokan dan kecepatan layanan.

\section{KESIMPULAN DAN SARAN}

Implementasi kebijakan penataan Pedagang Kaki Lima di Kecamatan Sintang, di pengaruhi oleh empat faktor yaitu faktor komunikasi, sumber daya, disposisi atau sikap aparatur dan struktur birokrasi:Komunikasi merupakan faktor pendukung dalam implementasi kebijakan penataan Pedagang Kaki Lima di
Kecamatan Sintang. Komunikasi dilakukan oleh Pemerintah Daerah Kabupaten Sintang melalui instansi terkait yaitu Dinas Perindustrian, Perdagangan, Koperasi dan UKM, dan Satuan Polisi Pamong Praja Kabupaten Sintang dalam bentuk sosialisasi, pembinaan dan penegakan aturan terhadap Pedagang Kaki Lima di Kecamatan Sintang.Dalam implementasi kebijakan penataan Pedagang Kaki Lima di Kecamatan Sintang sumber daya manusia aparatur pelaksana kebijakan sudah memadai dan merupakan faktor pendukung, sedangkan sumber daya peralatan berupa sarana dan prasarana untuk PKL dan anggaran masih terbatas sehinggga dapat dikatakan sebagai faktor kendala. Disposisi atau sikap aparatur dalam implementasi kebijakan penataan Pedagang Kaki Lima di Kecamatan Sintang memiliki komitmen yang kuat untuk penataan Pedagang Kaki Lima. Komitmen tersebut, diwujudkan dalam bentuk penegakan regulasi kebijakan, upaya persuasif dan represif pembinaan para Pedagang Kaki Lima yang terdapat di Kecamatan Sintang. Struktur birokrasi dalam implementasi kebijakan penataan Pedagang Kaki Lima di Kecamatan Sintang dapat dikatakan sudah baik hal ini terlihat dari dilaksanakannya koordinasi lintas instansi terkait dan berbagai stakeholder yang berhubungan dengan Penataan Pedagang Kaki Lima di Kecamatan Sintang.

Disarankan hal-hal sebagai berikut: dalam merumuskan kebijakan yang berkaitan dengan penataan pedagang kaki lima khususnya yang berada di Kecamatan Sintang, sebaiknya Pemerintah Daerah Kabupaten Sintang memperhatikan sebagai aspirasi yang datang dari masyarakat luar dan para Pedagang Kaki Lima, hal ini dalam rangka untuk efektivitas komunikasi dalam implementasi kebijakan Penataan Pedagang Kaki Lima ke depan, khususnya yang berada di Kecamatan Sintang. Dalam Penataan Pedagang Kaki Lima di Kecamatan Sintang pada masa yang akan datang sebaiknyaa Pemerintah Daerah Kabupaten Sintang dapat mengalosasikan dana sesuai dengan kebutuhan pengadaan sarana dan prasarana penempatan Pedagang Kaki Lima di Kecamatan Sintang. Sebaiknya Pemerintah 
Daerah Kabupaten Sintang dapat mempertahankan sikap aparatur dalam implementasi kebijakan penataan Pedagang Kaki Lima di Kecamatan Sintang yang memiliki komitmen kuat untuk penataan Pedagang Kaki Lima di Kecamatan

\section{DAFTAR PUSTAKA}

Islmy,M.Irfan. (2000). Perinsip-Perinsip Perumusan Kebijakan Negara. Jakarta: Bumi Akasara

Nugroho. Riant. (2004). Kebijakan Publik: Formulasi,Implementasi Dan Evaluasi. Jakarta: PT. Gremedia

Nugroho. Riant. (2011). Public Policy: Dinamika Kebijakan,Analisis Kebijakan dan Manajemen Kebijakan. Jakarta: PT. Elex Media Komputindo

Pemerintah Daerah Kabupaten Sintang. (1999). Peraturan Daerah Kabupaten Sintang Nomor 5 Tahun 1999 Tentang Retrubusi Izin Mendirikan Bangunan. Sintang : BAPPEDA Kabupaten Sintang.

Pemerintah Daerah Kabupaten Sintang. (2006). Rencana Tata Ruang Wilayah Kabupaten Sintang 2006-2016. Sintang, BAPPEDA Kabupaten Sintang

Pemerintah Daerah Kabupaten Sintang. (2011). Peraturan Daerah Kabupaten
Sintang. Struktur birokrasi yang sudah baik dapat dilaksanakan secara kosisten di masa yang akan datang guna efektivitas dalam implementasi kebijakan penataan Pedagang Kaki Lima di Kecamatan Sintang.

Sintang Nomor 9 Tahun 2011 Tentang Penataan Pedagang Kaki lima di Kabupaten Sintang. Sintang : BAPPEDA Kabupaten Sintang

Rakhmat, J. (2001). Metode Penelitian Komunikasi : Dilengkapi Contoh Analisis Statistik. Bandung : Remaja Rosdakarya.

Subarsono, A.G.(2005). Analisis Kebijakan Publik: Konsep, Teori dan Aplikasi. Yogyakarta : Pustaka Pelajar

Sugiyono. (2005). Memahami Penelitian Kualitatif. Bandung : Alfabeta

Sugiyono. (2008). Metode Penelitian Administrasi. Bandung : Alfabeta

Widodo, Joko. (2007). Analisis Kebijakan Publik. Bandung : Bayumedia Publishing

Winarno, Budi. (2002). Teori Dan Prosoes Kebijakan Publik. Yogyakarta: Media Pressendo 